\title{
IAMJ
}

INTERNATIONAL

AYURVEDIC

MEDICAL JOURNAL

\section{TO STUDY THE EFFICACY OF POLY HERBO-MINERAL COMPOUND IN THE MANAGEMENT OF GRADE I \& GRADE II FATTY LIVER (HEPATIC STEATOSIS)}

\author{
$\underline{\text { Nabaruna Bose }}^{1}, \underline{\text { O.P. Gupta }}{ }^{2}, \underline{\text { Bishnu Prasad Sarma }}^{3}$
}

${ }^{1}$ PG Scholar, Dept. of Kayachikitsa, Govt. Ayurvedic College, Guwahati-14, Assam, India

${ }^{2}$ Professor, Dept. of Kayachikitsa, Govt. Ayurvedic College, Guwahati-14, Assam, India

${ }^{3}$ Professor, Ex-HOD, Dept. of Kayachikitsa, Govt. Ayurvedic College, Guwahati-14, Assam, India

Corresponding Author: bose.nabaruna@gmail.com

https://doi.org/10.46607/iamj01p5052021

(Published Online: July 2021)

Open Access

(C) International Ayurvedic Medical Journal, India 2021

Article Received: 21/06//2021 - Peer Reviewed: 24/06/2021 - Accepted for Publication: 26/06/2021

\section{Check for updates}

\section{ABSTRACT}

Hepatic Steatosis is a common predicament in society due to changes in lifestyle and food practices. Depending upon the cause and amount of accumulation, fatty change may be mild and reversible, or severe producing irreversible cell injury and cell death. Disturbances of lipid metabolism in the liver due to various etiological factors lead to Fatty Liver. Ayurveda has immense potential in the management of Non-Communicable Diseases, and Fatty liver is one among them. In Ayurveda, a direct correlation of Fatty liver is not found but it can be considered under Yakrit roga and Medo roga, as a Santarpanjanya Vyadhi. Hepatic steatosis patients are treated with Triphaladi yoga and Yashtimadhu churna for 3 months, in the Department of Kayachikitsa, Govt. Ayurvedic College and Hospital, Guwahati. This trial aims to formulate a practical Ayurvedic protocol for the management of Grade I and Grade II Fatty liver. However, further research studies are needed to fulfil the aims and objectives.

Keywords: Yakrit Roga, Hepatic steatosis, Santarpanjanya Vyadhi, poly-herbo mineral compound, clinical trial. 


\section{INTRODUCTION}

Ayurveda is a holistic system of medicine. It has a great role in lifestyle disorders. So, the changing lifestyle with food habits affects health along with liver too. Fatty liver is a very common disorder and refers to a condition where there is an accumulation of excess fat in the hepatocytes in the form of triglycerides. There are effective herbs available in Ayurveda for chronic diseases like fatty liver. It not only occurs in obese people but $7 \%$ of the lean population is affected too. Hepatocytes perform numerous and vital roles in maintaining homeostasis and health. These functions include synthesis of serum proteins, metabolism of protein, fats and carbohydrates, storage of Vitamin $\mathrm{A}, \mathrm{D}, \mathrm{B}_{12}$ and glycogen, coagulation factors, bile and bile acids etc. Fatty liver is a reversible condition wherein a large amount of fat accumulate in liver cells via the process of steatosis. When fat content exceeds $5 \%$ of the total weight of the liver or more than $30 \%$ of liver cells in a liver lobule are with a fat deposit, this condition is called Fatty Liver. The aetiology of the Fatty Liver mainly falls under two categories. The first category comprises the conditions with excess fat which imparts increased workload to the liver for metabolizing fat. The second category involves conditions of liver cell damage in which fat cannot be metabolized due to liver cell injury.

\section{Etiology of Fatty Liver ${ }^{[1]}$}

1. Conditions with excess fat: Obesity, Diabetes mellitus, Congenital hyperlipidaemia

2. Liver cell damage: Alcoholic Liver Disease (most common), Starvation, Protein calorie malnutrition, Chronic illness (e.g. TB), Acute fatty liver in late pregnancy, Hypoxia (Anemia, cardiac failure), Hepatotoxins (Carbon tetrachloride, chloroform, ether, aflatoxin), Druginduced liver cell injury (methotrexate, CCl4., steroids, halothane anaesthetic, tetracycline etc), Reye's Syndrome

Fatty Liver can be both -

1. Alcoholic Fatty Liver and

2. Non-Alcoholic Fatty Liver.
According to Modern medicine, the fatty liver pathology has been classified into ${ }^{[2]}{ }_{-}$

\section{NON-ALCOHOLIC FATTY LIVER(NAFL)}

Presence of hepatic steatosis (fat accumulation) with no evidence of hepatocellular injury in the form of ballooning of the hepatocytes or no evidence of fibrosis. The risk of progression to cirrhosis and liver failure is minimal.

\section{NON-ALCOHOLIC FATTY LIVER DISEASE(NAFLD)}

Encompasses the entire spectrum of fatty liver disease in individuals without significant alcohol consumption ranging from fatty liver to steatohepatitis to fibrosis and cirrhosis.

\section{ALCOHOLIC LIVER DISEASE}

- Chronic and excessive use of alcohol ingestion is one of the major causes of liver disease. Alcoholic liver disease mainly comprises - (i) fatty liver, (ii) alcoholic hepatitis and (iii) cirrhosis.

- Fatty liver is present in more than $90 \%$ of daily as well as binge drinkers.

Fatty liver is now a growing problem worldwide. Although fatty liver in itself is not fatal it cripples the affected patients and alcoholic fatty liver if not treated, then it can progress to steatohepatitis to cirrhosis of the liver which is irreversible. In India $16 \%-32 \%$ of urban and $9 \%$ of the rural population are affected according to THE INDIAN NATIONAL ASSOCIATION FOR STUDY OF THE LIVER (INASL) which was renamed from THE LIVER STUDY GROUP OF INDIA in 1992 having the parent association as INDIAN SOCIETY OF GASTROENTEROLOGY formed in the year 1960. The prevalence increased significantly $80-90 \%$ in obese adults, $60 \%$ in patients with hyperlipidemia and $30-50 \%$ in diabetic patients. In India, it is emerging as an important cause of liver disease. Ayurveda has immense potential in the management of non-Communicable diseases and NAFLD is one of them.

There is no description of Yakrit vikara as a separate chapter in Ayurvedic classics, only Bhavaprakasha mentioned it as a separate chapter. Description of 
Yakritdalyodara is found while describing Pleehodara in the Brihat Trayees. All Roga's are known to occur due to Mandagni and specially Udara Roga's ${ }^{[3]}$. In Ayurveda, Fatty liver may be understood in light of Yakritodara and Medoroga. Meda is the fourth Dhatu as per Ayurveda doctrine and resembles adipose tissue, which in its natural state, maintains Snigdhata and provides Bala to the body. But when the quantity of Meda increases from normal, it causes various structural and functional abnormalities in the body. According to Acharya Charaka, Avyayama, Divaswapna, excessive intake of Medasvi Dravya and Varuni Madya are the causative factors of Medovaha srotodushti [4]. Excessive intake of these ahara viharas leads to Jatharagni mandyata and decrease the Medodhatwagni. If the Meda Dhatwagni is deregulated then there is disharmony of distribution of Baddha Meda (stored in a particular site) and Abaddha Meda ${ }^{[5]}$ (circulating fat). This Baddha Meda can be termed as visceral fat and Abaddha Meda can be understood as circulating lipids which leads to Medovriddhi and that excessive Meda deposits in various parts of the body including Yakrit which impairs the proper function. The excessive fat deposit in the liver causes fatty liver, which is lack of treatment can cause serious conditions. From this phenomenon, it can be said that Meda not only creates Sthaulya it can create Yakritmeda too. Madya is another common nidana nowadays for the development of steatosis. It is a common raktadushaka dravya and also causes Medovaha srotodushti ${ }^{[4]}$.Madya has the following qualities: Laghu, Ushna, Tikshna, Sukshma, Vishada, Amla, Ashu, Vikasi and Ruksha ${ }^{[6]}$. All Madya are generally, Pittakara and Vatahara in nature. Madya is considered as sannikrishta nidana leading to Yakritodara. The guna of Madya causes srototanutva in Yakrit and brings sithilata in dhatu leading to medo dushti and then sanchaya of udaka in udara Pradesh in between twaka and mamsa.

\section{The probable Samprapti may be:}

Nidanasevana (Vidahi and abhishyandhi ahaara)<smiles>C1=C[CH]C=1</smiles>

Kapha \& pitta gets dushita<smiles>[CH]=C</smiles>

Jatharagnimandyata (Impaired fatty acid metabolism)

Aam formation
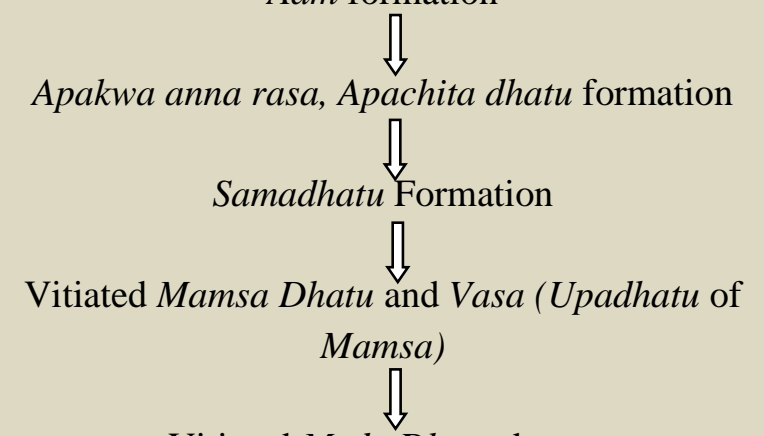

Vitiated Meda Dhatu due to

$$
\text { Medodhatwagnimandyata }
$$

Increased production of Abaddha Meda or Durmeda

Causing Srotavarodh in Raktavaha, Mamsavaha and Medovaha Srota

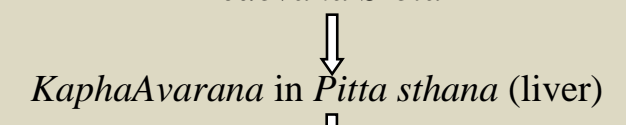

Accumulation of Meda and Vasa (fat or triglycerides) in Yakrit as Vasa is Upadhatu of

Mamsa<smiles>[CH]=C</smiles>

Sneha Guna and Kledaka Guna will increase and Ushna Guna will decrease in Yakrit.

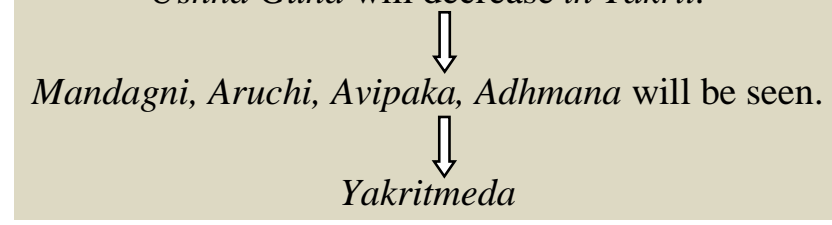

\section{Samprapti Ghataka:}

- Dosha - Kapha-pitta pradhana tridosaja, VataPrana, Vyana, Apana, Samana, Pitta - Pachaka, Kapha-Kledaka, Avalambaka

- Dushya-Rasa, Rakta, Mamsa

- Agni dushti-Jatharagni, Dhatwagni mandyata. 
- Srota - Annavaha, Rasavaha, Raktavaha, Purishavaha

- Udbhavsthana-Amasaya

- Adhisthana-Udara

- Vyaktasthana - Yakrita, Pleeha, Udara

- Rogamarga-Abhyantara

The management should be the breakdown of pathological factors like kaphamedodushti, sroto avarodha and agnivaigunya. A practical treatment protocol including Virechana (Purgation), Shamana (Pacification) and lifestyle modification with due importance to the bodily constitution (prakriti) can help in the proper management of the disease. Based on the samprapti and the dosha involved the drugs which are having Tikta, Kasaya Rasa, Lekhana, Deepana and Pachana properties, which increase the power of Agni and reduce Kapha, Meda and Ama are the choice of drugs for the management of Fatty liver. Considering all the above qualities Triphaladi Yoga ${ }^{[7]}$ mentioned in Charak Samhita, Pandurogachikitsa along with Yashtimadhu churna ${ }^{[8]}$ included in Haritakyadi varga by BhavaPrakash is chosen for the study. Here in this study, an attempt is made to find out the efficacy of Triphaladi yoga and Yashtimadhu churna in the management of Grade I \& Grade II fatty liver.

Aim: To evaluate the clinical efficacy of a poly herbo-mineral compound and Yashtimadhu Churna in Grade I \& Grade II fatty liver.

\section{Objectives:}

1. To assess the beneficial effects of the poly herbo-mineral compound and Yashtimadhu Churna in Grade I \& Grade II fatty liver.

2. To find out the adverse effect of the poly herbomineral compound and Yashtimadhu Churna in Grade I \& Grade II fatty liver (if any).

\section{Materials and Methods}

- Sample size: 32

- Source of data: Total 32 patients in both OPD and IPD basis, having age in between 18-70 years, irrespective of sex, occupation, religion, in the Department of Kayachikitsa, Govt. Ayurvedic College and Hospital, Guwahati are selected for the clinical trial.
Method of collection of Data: Patients fulfilling the inclusion criteria are selected for the study. Before starting the treatment, detailed clinical history is taken in the clinical research proforma based on Ayurvedic and modern parameters and the written consent is taken from patients. The study has conducted as an open labelled interventional clinical trial after received written consent from The Institutional Ethical Committee.

\section{Inclusion Criteria:}

- Patients between 18 to 70 years of age irrespective of sex.

- Subjects having complaints of indigestion, pain abdomen, anorexia, fatigue, nausea and fulfilling the criteria of diagnosis.

- Obese subjects.

Exclusion Criteria: Subjects below 18 years more than 70 years., Pregnancy and lactation, Severe cardiac problems, Psychiatric disorders., Stomach ulcers, Cancer patients, Surgical intervention if any.

\section{Diagnostic Criteria:}

Subjective Criteria:

History taking: Family history of liver pathology, obesity., Diet history (if fatty diet, alcohol), history of any viral infections., Personal history, Fatigability, Pain in the right upper quadrant.

\section{Physical Examination:}

- To see if there is any swelling in the right upper abdomen.

- Palpating right upper quadrant.

- Tenderness in the right upper quadrant

\section{Objective Criteria:}

- USG Whole abdomen

- Haematological- Blood for routine examination, Liver Function Test, Lipid Profile

- Urine for Routine examination

Assessment of Result: The assessment was done on a detailed proforma based on both subjective and objective criteria.

Subjective Parameters: Indigestion, Anorexia, Abdominal bloating, Nausea, Fatigue, Pain abdomen. Objective Parameters: USG whole abdomen, Lipid Profile, Liver Function Test. 
Intervention and Posology: Triphalyadi Yoga: 8 ratti (1 gm) daily which was given on two divided doses i.e. $500 \mathrm{mg}$ twice a day after food for 3 months, Yashtimadhu churna: $2 \mathrm{gm}$ twice daily after food for 3 months with warm water or honey. Duration of the study: 3 months duration., Follow up interval: 30 days or if necessary.
Data Analysis: All the data collecting from case history records are placed, analyzed using appropriate statistical tools such as Arithmetic mean, percentage, standard deviation, Paired t-test and calculate $\mathrm{p}$ (probability) value.

Observation and Result: A total of 32 patients were enrolled for the present study.

\section{The result of Therapeutic profiles are:}

Table 1: Showing the Incidence and Improvement Of Different Signs And Symptoms Of Patients Among Male And Females Before And After Treatment (N=32)

\begin{tabular}{|c|c|c|c|c|c|c|c|c|c|c|c|c|c|c|c|}
\hline \multirow[t]{2}{*}{$\begin{array}{l}\text { Sl } \\
\text { No } \\
\text {. }\end{array}$} & \multirow[t]{2}{*}{$\begin{array}{l}\text { subjective } \\
\text { signs and } \\
\text { symptoms }\end{array}$} & \multicolumn{5}{|c|}{ Male $=9$} & \multicolumn{5}{|c|}{ Female $=23$} & \multicolumn{2}{|c|}{ total $=32$} & \multicolumn{2}{|c|}{$\begin{array}{l}\text { total } \\
\text { improvement } \\
\text { in } \%\end{array}$} \\
\hline & & $\begin{array}{l}\mathrm{B} \\
\mathrm{T}\end{array}$ & $\%$ & $\begin{array}{l}\mathrm{A} \\
\mathrm{T}\end{array}$ & $\%$ & $\begin{array}{l}\% \quad \text { of } \\
\text { Improvemen } \\
t\end{array}$ & $\begin{array}{l}\mathrm{B} \\
\mathrm{T}\end{array}$ & $\%$ & $\begin{array}{l}\mathrm{A} \\
\mathrm{T}\end{array}$ & $\%$ & $\begin{array}{l}\% \text { of } \\
\text { improvemen } \\
\mathrm{t}\end{array}$ & $\begin{array}{l}\mathrm{T}_{\mathrm{B}} \\
\mathrm{T}\end{array}$ & $\%$ & $\mathrm{~T}$ & $\%$ \\
\hline 1 & $\begin{array}{l}\text { Indigestio } \\
\mathrm{n}\end{array}$ & 8 & $\begin{array}{l}88.88 \\
\%\end{array}$ & 2 & $\begin{array}{l}22.22 \\
\%\end{array}$ & $66.67 \%(6)$ & 20 & $\begin{array}{l}86.95 \\
\%\end{array}$ & 2 & $8.69 \%$ & $78.26 \%(18)$ & 28 & $87.5 \%$ & 24 & $\begin{array}{l}85.71 \\
\%\end{array}$ \\
\hline 3 & Bloating & 6 & $\begin{array}{l}66.67 \\
\%\end{array}$ & 2 & $\begin{array}{l}22.22 \\
\%\end{array}$ & $44.44 \%(4)$ & 21 & $91.3 \%$ & 3 & $\begin{array}{l}13.04 \\
\%\end{array}$ & $78.26 \%(18)$ & 27 & $\begin{array}{l}84.37 \\
\%\end{array}$ & 22 & $\begin{array}{l}81.48 \\
\%\end{array}$ \\
\hline 4 & Nausea & 4 & $\begin{array}{l}44.44 \\
\%\end{array}$ & 1 & $\begin{array}{l}11.11 \\
\%\end{array}$ & $33.33 \%(3)$ & 5 & $\begin{array}{l}21.73 \\
\%\end{array}$ & 1 & $4.34 \%$ & $17.39 \%(4)$ & 9 & $\begin{array}{l}28.12 \\
\%\end{array}$ & 7 & $\begin{array}{l}77.78 \\
\%\end{array}$ \\
\hline 5 & Fatigue & 5 & $55.5 \%$ & 2 & $\begin{array}{l}22.22 \\
\%\end{array}$ & $33.33 \%(3)$ & 20 & $\begin{array}{l}86.95 \\
\%\end{array}$ & 2 & $8.69 \%$ & $78.26 \%(18)$ & 25 & $\begin{array}{l}78.12 \\
\%\end{array}$ & 21 & $84 \%$ \\
\hline
\end{tabular}

Incidence and improvement of different sign and symptoms of patients among male and female before and after treatment $(n=32)$

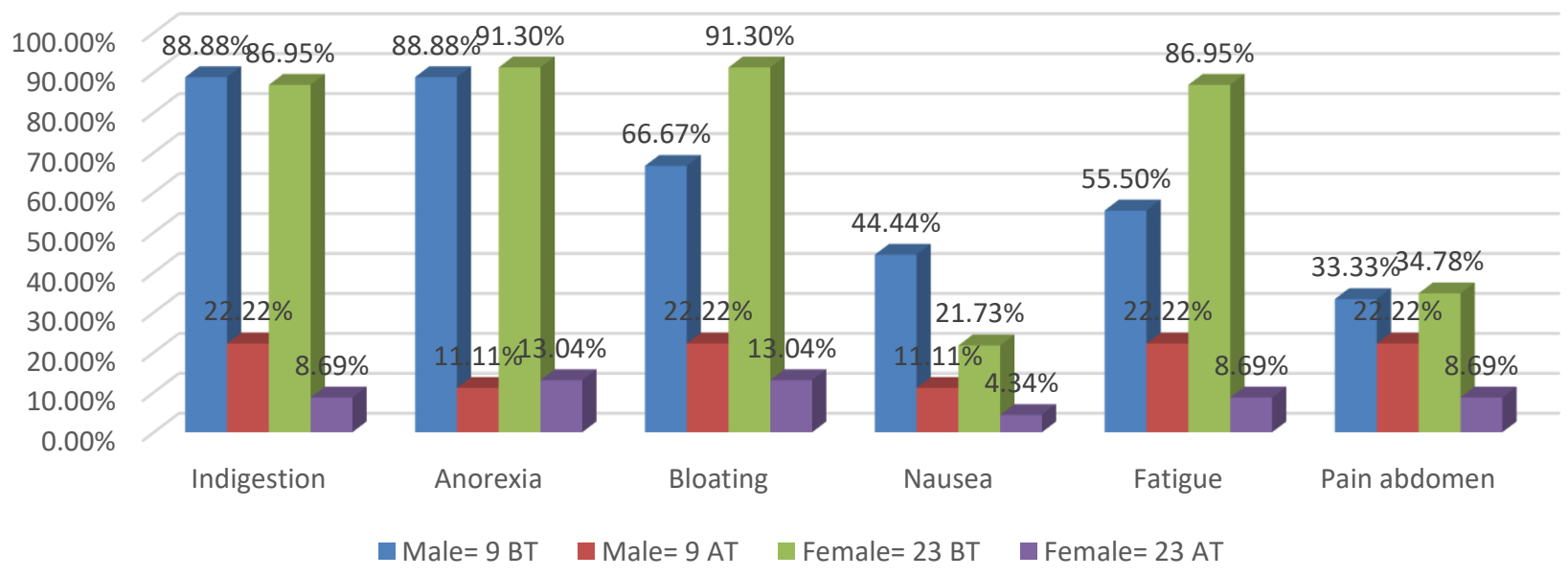

\section{Chart 1}


Table 2: Table Showing The Effect Of The Trial Drug On USG Whole Abdomen Findings $(\mathrm{N}=32)$

\begin{tabular}{|c|c|c|c|c|c|c|c|c|c|c|}
\hline $\begin{array}{l}\text { Mean } \\
\text { BT }\end{array}$ & $\begin{array}{l}\text { Mean } \\
\text { AT }\end{array}$ & $\begin{array}{l}\text { Difference of } \\
\text { mean }\end{array}$ & $\mathrm{SD}_{\mathrm{BT}}$ & $\mathrm{SD}_{\mathrm{AT}}$ & $\mathrm{SEM}_{\mathrm{BT}}$ & $\mathrm{SEM}_{\mathrm{AT}}$ & $\begin{array}{ll}\text { SE } & \text { of } \\
\text { Difference }\end{array}$ & $\mathrm{t}_{31}$ & $\mathrm{P}$ & Remarks \\
\hline 1.31 & 0.16 & 1.16 & 0.47 & 0.37 & 0.08 & 0.07 & 0.065 & 17.7303 & .0001 & S \\
\hline
\end{tabular}

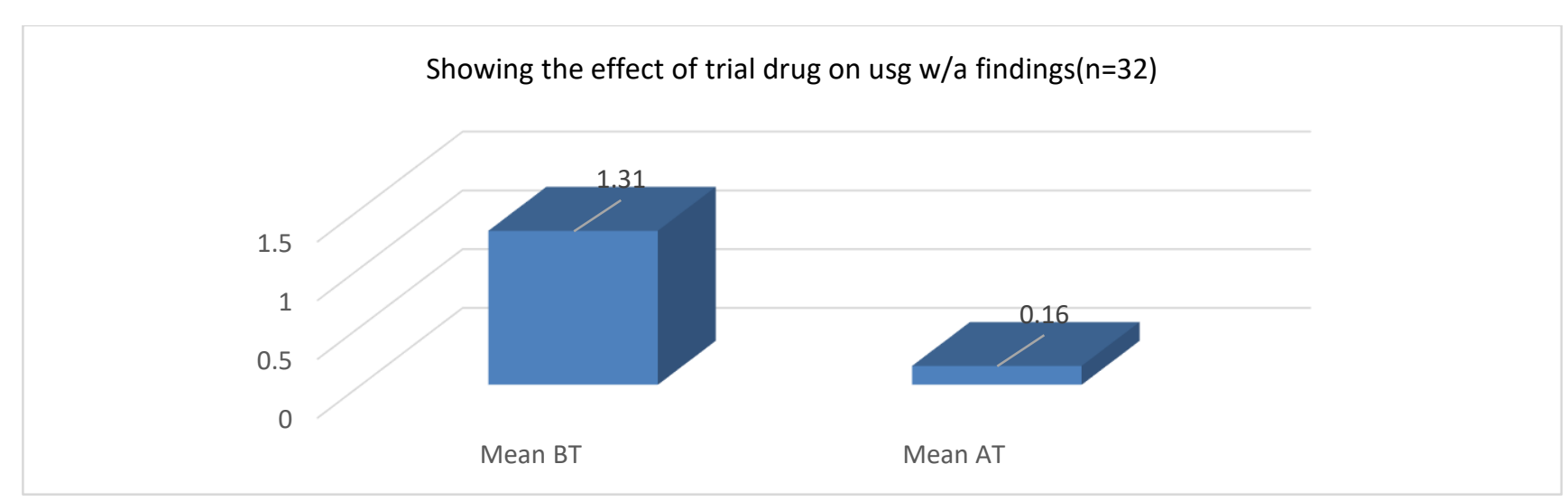

Chart 2

Table 3: Table Showing The Effect Of Trial Drug On SGPT Or ALT (N=32)

\begin{tabular}{|l|l|l|l|l|l|l|l|l|l|l|l|}
\hline $\begin{array}{l}\text { Mean } \\
\text { BT }\end{array}$ & $\begin{array}{l}\text { Mean } \\
\text { AT }\end{array}$ & $\begin{array}{l}\text { Difference of } \\
\text { mean }\end{array}$ & SD $_{\text {BT }}$ & SD $_{\text {AT }}$ & SEM $_{\text {BT }}$ & SEM $_{\text {AT }}$ & $\begin{array}{l}\text { SE } \\
\text { Difference }\end{array}$ & $t_{31}$ & P & Remarks \\
\hline 44.25 & 36.94 & 7.31 & 5.20 & 2.96 & 0.92 & 0.52 & 0.676 & 10.8226 & 0.0001 & $\mathrm{~S}$ \\
\hline
\end{tabular}

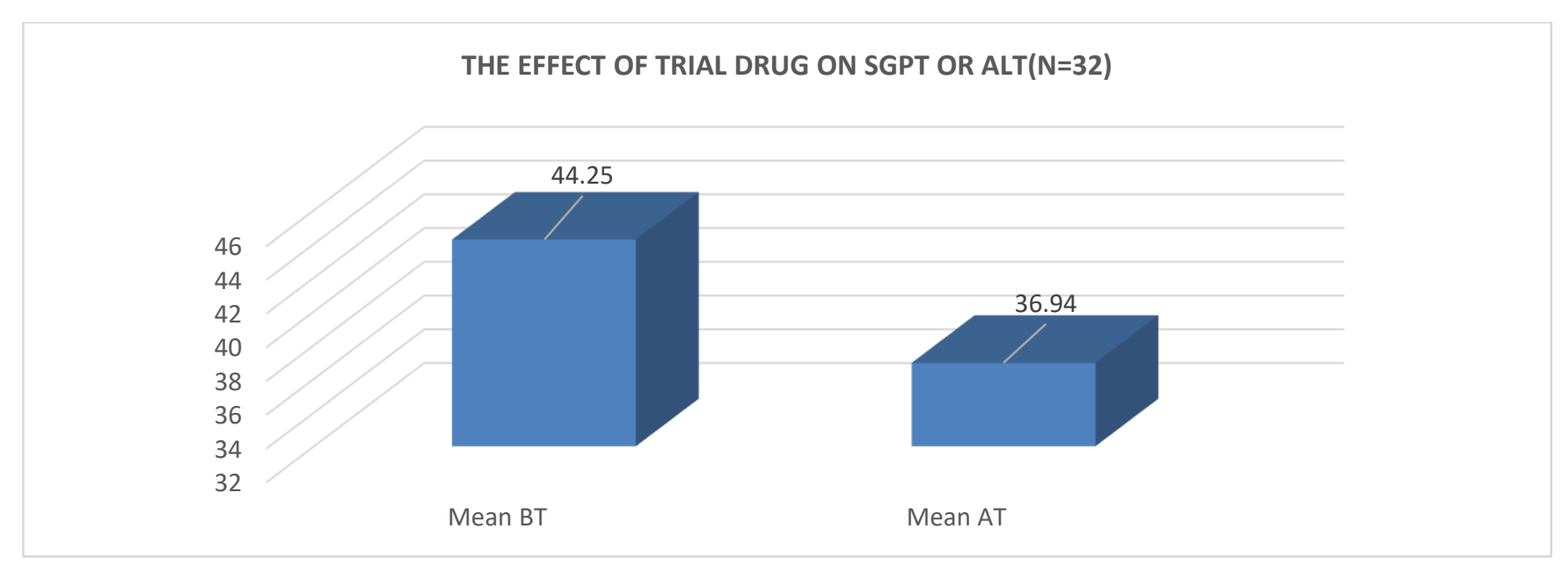

Chart 3

Table 4: Table Showing The Effect Of Trial Drug On SGOT Or AST(N=32)

\begin{tabular}{|l|l|l|l|l|l|l|l|l|l|l|}
\hline $\begin{array}{l}\text { Mean } \\
\text { BT }\end{array}$ & $\begin{array}{l}\text { Mean } \\
\text { AT }\end{array}$ & $\begin{array}{l}\text { Difference } \\
\text { of mean }\end{array}$ & $\mathrm{SD}_{\mathrm{BT}}$ & $\mathrm{SD}_{\mathrm{AT}}$ & $\mathrm{SEM}_{\mathrm{BT}}$ & $\mathrm{SEM}_{\mathrm{AT}}$ & $\begin{array}{l}\mathrm{SE} \text { of } \\
\text { Difference }\end{array}$ & $\mathrm{t}_{31}$ & $\mathrm{P}$ & Remarks \\
\hline 40.81 & 35.53 & 5.28 & 4.71 & 2.34 & 0.83 & 0.492 & 0.548 & 10.7266 & .0001 & $\mathrm{~S}$ \\
\hline
\end{tabular}




\section{THE EFFECT OF TRIAL DRUG ON SGOT OR AST(N=32)}

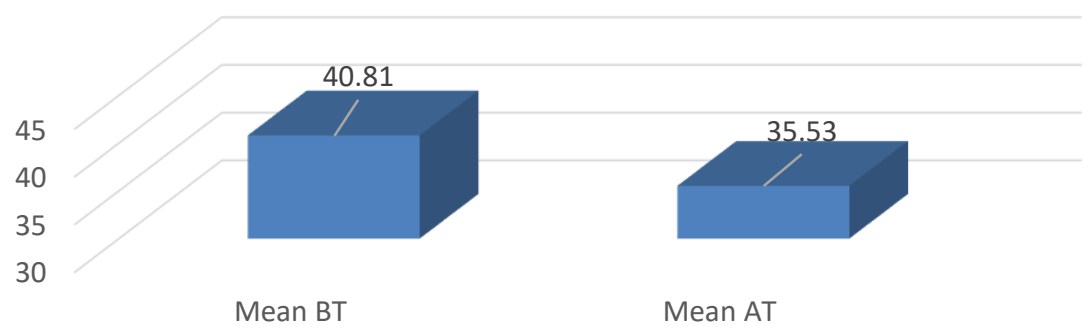

Chart 4

Table 5: Table Showing The Effect Of Trial Drug On Serum Triglycerides $(\mathrm{N}=32)$

\begin{tabular}{|l|l|l|l|l|l|l|l|l|l|l|}
\hline $\begin{array}{l}\text { Mean } \\
\text { BT }\end{array}$ & $\begin{array}{l}\text { Mean } \\
\text { AT }\end{array}$ & $\begin{array}{l}\text { Difference } \\
\text { of mean }\end{array}$ & SD $_{\mathrm{BT}}$ & $\mathrm{SD}_{\mathrm{AT}}$ & $\mathrm{SEM}_{\mathrm{BT}}$ & $\mathrm{SEM}_{\mathrm{AT}}$ & $\begin{array}{l}\text { SE of } \\
\text { Difference }\end{array}$ & $\mathrm{t}_{31}$ & $\mathrm{P}$ & Remarks \\
\hline 150.84 & 135.38 & 15.47 & 22.78 & 9.78 & 4.03 & 1.73 & 3.295 & 4.6951 & .0001 & $\mathrm{~S}$ \\
\hline
\end{tabular}

\section{SHOWING THE EFFECT OF TRIAL DRUG ON SERUM TRIGLYCERIDES(N=32)}

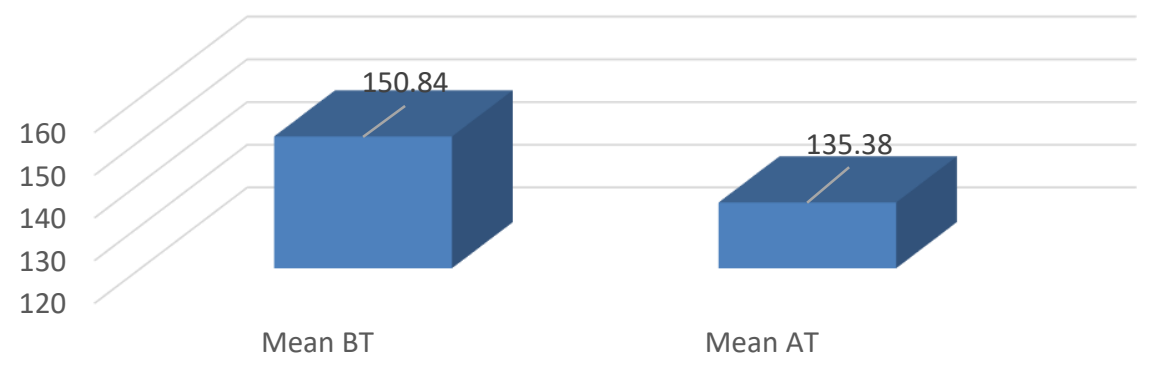

\section{Chart 5}

Table 6: Table Showing The Effect Of Trial Drug On Serum LDL (N=32)

\begin{tabular}{|l|l|l|l|l|l|l|l|l|l|l|}
\hline $\begin{array}{l}\text { Mean } \\
\text { BT }\end{array}$ & $\begin{array}{l}\text { Mean } \\
\text { AT }\end{array}$ & $\begin{array}{l}\text { Difference } \\
\text { of mean }\end{array}$ & $\mathrm{SD}_{\mathrm{BT}}$ & $\mathrm{SD}_{\mathrm{AT}}$ & $\mathrm{SEM}_{\mathrm{BT}}$ & $\mathrm{SEM}_{\mathrm{AT}}$ & $\begin{array}{l}\mathrm{SE} \text { of } \\
\text { Difference }\end{array}$ & $\mathrm{t}_{31}$ & $\mathrm{P}$ & Remarks \\
\hline 121.25 & 117.66 & 3.59 & 8.55 & 9.46 & 1.51 & 1.67 & 0.580 & 6.1960 & .0001 & $\mathrm{~S}$ \\
\hline
\end{tabular}




\section{SHOWING THE EFFECT OF TRIAL DRUG ON SERUM LDL ( $\mathrm{N}=32$ )}

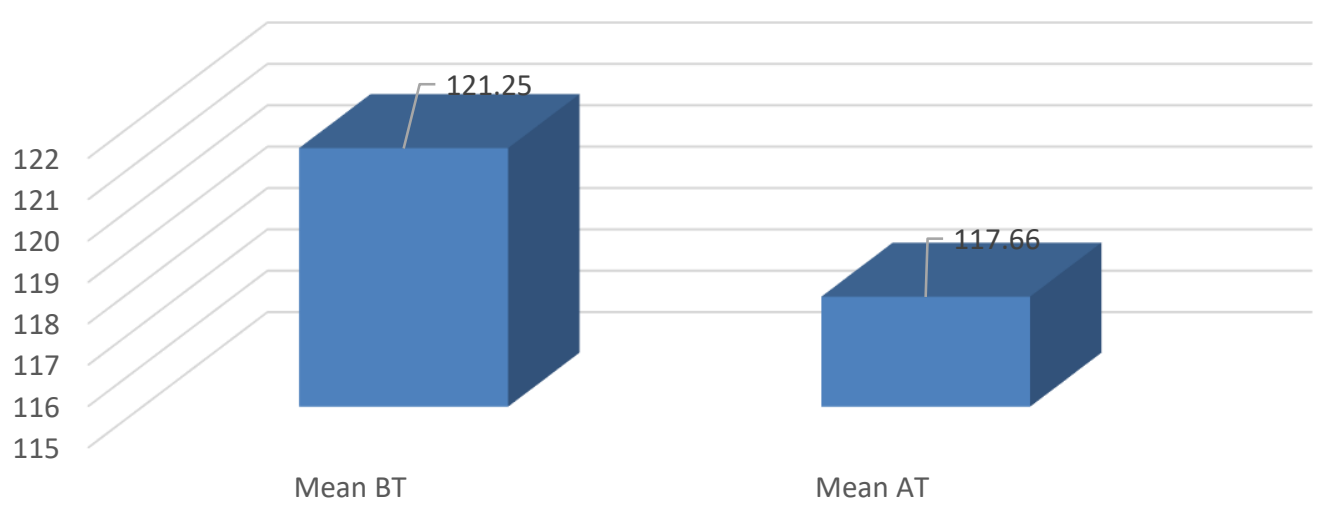

\section{Chart 6}

\section{DISCUSSION}

Fatty liver is a reversible condition wherein a large amount of fat accumulate in liver cells via the process of steatosis. When fat content exceeds $5 \%$ of the total weight of the liver or more than $30 \%$ of liver cells in a liver lobule are with a fat deposit, this condition is called Fatty Liver (Hepatic steatosis). In Ayurveda, we cannot co-relate Hepatic steatosis with any single disease but it can be co-related with Yakritodara, Sthaulya or Medoroga and may be termed as Yakritmeda. Triphalyadi Yoga contains Triphala,Haridra, Daruharidra, Kutki and Lauha Bhasma and along with it, Yashtimadhu Churna is also used. Triphala ${ }^{[9]}$ has Deepaniya action, SleshmaPittaghna which reduces the aggravated Kapha and Meda , Rasayni(Rejuvenation), Ruchikara properties which improve anorexia. Haridra ${ }^{[11]}$ due to its TiktaKatu rasa, Ushna Virya, Katu Vipaka and Laghu, Ruksha Guna makes be Deepaniya, Pachaniya and Lekhaniya help in removing the excess fat and clearing out channels and improving the function of the Liver. Daruharidra ${ }^{[12]}$ has Tikta-kasaya rasa, Laghu-Ruksha Guna, Katu Vipaka and Ushna Virya and is Lekhaniya. Kutki ${ }^{[10]}$ has Tikta Rasa, RukshaLaghu Guna, Katu Vipaka and Shita Virya, Deepaniya , Ruchikara and Bhedaniya. Lauha Bhasma $^{[13]}$ is Ruksha, Tikta,Kasaya , Madhura, Tridoshanashaka, Deepaniya ,Lekhaniya, Yogavahi, Rasayani (Rejuvination ),Medonirvahanam.
Yashtimadhu ${ }^{[8]}$ has Deepaniya, Pachaniya property helps in Ama pachan, Rochana which stimulates appetite, Rasayani(Rejuvenation), Yakrituttejaka. If we see the Ayurvedic properties along with the therapeutic evaluation or the results of various clinical and experimental research already done on the individual plants, it shows that all of them have Lekhaniya and Medohara actions which play a role in fat deposition in the liver directly or indirectly without any adverse side effect. The patients were also advised to walk daily for 30 minutes. The result of the therapeutic trial showed that- the effect of oral polyherbomineral compound is effective. In all criteria, p values are less than 0.0001 and highly show significance.

\section{CONCLUSION}

Fatty liver is more common nowadays due to change in lifestyle, affecting millions of people around the world. No established pharmacological treatment is available for Fatty liver in conventional medical science. Several empirical treatment strategies such as dietary restriction, physical exercise and weight reduction form the first line of treatment. Oral Ayurvedic Polyherbomineral formulations are much more convenient to reduce the symptoms and help to protect the liver. Therefore, the combination of drugs has shown a significant effect on hepatic steatosis. 
However, beyond the present clinical trial, further mass study is required to establish the research drug.

\section{REFERENCES}

1. Textbook of Pathology by Harsh Mohan $7^{\text {th }}$ edition chapter 2-page no.19.

2. Harrison's Principle of Internal Medicine by Kasper, Fauci, Hauser, Longo, Jameson, Loscalzo $19^{\text {th }}$ edition Chapter 364 and 365, page no.2052-2054.

3. Kaviraj Atridev Gupta, Vidyotani, Vidyalankar Bhishagratna, Edited with Vidyotani Hindi Commentary Ashtanga Hridaya, Nidansthan Udara Nidana Adhyaya 12/1, Chaukhamba Prakashan, Varanasi, Reprint, 2014; 339.

4. Shastri Kashinath, Chaturvedi Gorakhnath edited Charak Samhita of Agnivesha, Revised by Charak and Dridhabala, Part I, Chaukhamba Bharati Academy, Varanasi, Reprint, 2009; Vimana Sthana 5/9: Page no.713.

5. Shastri Kashinath, Chaturvedi Gorakhnath edited Charak Samhita of Agnivesha, Revised by Charak and Dridhabala, Part I, Chaukhamba Bharati Academy, Varanasi, Reprint, 2009; Nidana Sthana 4/7: P-632.

6. Shastri Kashinath, Chaturvedi Gorakhnath edited Charak Samhita of Agnivesha, Revised by Charak and Dridhabala, Part I, Chaukhamba Bharati Academy, Varanasi, Reprint, 2009; Chikitsa Sthana 24/30: Page no.671.

7. Shastri Kashinath, Chaturvedi Gorakhnath edited Charak Samhita of Agnivesha, Revised by Charak and Dridhabala, Part I, Chaukhamba Bharati Academy, Varanasi, Reprint, 2009; Chikitsa Sthana 16/99: Page no. 902 .

8. Bhava Misra, Bhavprakash, Purva Khanda, Pratham Bhaga, Chowkhamba Krishnadas Academy, Varanasi, Reprint 2011; Haritakyadi Varga, Page No.181.

9. Bhava Misra, Bhavprakash, Purva Khanda, Pratham Bhaga, Chowkhamba Krishnadas Academy, Varanasi, Reprint 2011; Haritakyadi Varga, Page No.164.

10. Bhava Misra, Bhavprakash, Purva Khanda, Pratham Bhaga, Chowkhamba Krishnadas Academy, Varanasi, Reprint 2011; Haritakyadi Varga, Page No.182.

11. Bhava Misra, Bhavprakash, Purva Khanda, Pratham Bhaga, Chowkhamba Krishnadas Academy, Varanasi, Reprint 2011; Haritakyadi Varga, Page No.191.

12. Bhava Misra, Bhavprakash, Purva Khanda, Pratham Bhaga, Chowkhamba Krishnadas Academy, Varanasi, Reprint 2011; Haritakyadi Varga, Page No.192.
13. Prof. Dattatreya Ananta Kulkarni, Rasaratnasammuchaya, Prathama Bhaga, Meharchand Lachhmandas Publication, New Delhi, Reprint 2010; Panchamadhyaya, Sloka 136-139, Page No.120

\section{Source of Support: Nil \\ Conflict of Interest: None Declared}

How to cite this URL: Nabaruna Bose \& O.P. Gupta: To Study The Efficacy Of Poly Herbo-Mineral Compound In The Manage-Ment Of Grade I \& Grade II Fatty Liver. International Ayurvedic Medical Journal \{online\} 2021 \{cited July 2021\} Available from: http://www.iamj.in/posts/images/upload/2959_2967.pdf 